\title{
Kontribusi Pasar Saham Syariah Terhadap Pertumbuhan Ekonomi Indonesia
}

\author{
Binti Shofiatul Jannah \\ Universitas Islam Negeri Sunan Ampel Surabaya \\ Email: bintishofiatul@gmail.com
}

https://doi.org/10.30741/wiga.v9i2.463

INFO A R T I KEL

Tanggal masuk :

10 Agustus 2019

Tanggal Revisi :

20 September 2019

Tanggal Diterima :

30 September 2019

\section{A B S T R A K}

Penelitian ini bertujuan untuk menyelidiki kontribusi perkembangan pasar saham Syariah terhadap pertumbuhan ekonomi Indonesia. Produk domestik bruto (PDB) adalah nilai pasar semua barang dan jasa yang diproduksi oleh suatu negara pada periode tertentu. PDB merupakan salah satu metode untuk menghitung pendapatan nasional. Indeks saham Syariah yang digunakan adalah Jakarta Islamic Index (JII) yang telah beridiri lama. Oleh karena itu, sampel penelitian terdiri dari indeks JII (Jakarta Islamic Indexs) dan PDB (Produk Domestik Bruto). Periode penelitian kurang lebih selama 16 tahun amatan mulai dari tahun 2000 sampai 2016. Data diperoleh dari publikasi di website IDX (Indonesia Stock Exchange), OJK (Otoritas Jasa Keuangan) dan BPS (Badan Pusat Statistik). Beberapa pengujian seperti uji unit root, uji cointergration dan Error Correction Model digunakan untuk menguji data. Alat uji statistik yang digunakan adalah Eviews 9. Hasil Error Correction Model menunjukkan bahwa pasar saham Syariah tidak berpengaruh terhadap pertumbuhan ekonomi dalam jangka panjang.

Kata kunci: Pasar Modal Syariah, Jakarta Islamic Indeks, Produk Domestik Bruto, Pertumbuhan Ekonomi

\begin{abstract}
A B S T R A C T
Contribution of the Islamic Stock Market to Indonesia's Economic Growth. This study aims to investigate the contribution of the development of the Islamic stock market to Indonesia's economic growth. Gross domestic product $(G D P)$ is the market value of all goods and services produced by a country in a certain period. GDP is one method for calculating national income. The Islamic stock index used is the Jakarta Islamic Index (JII) which has long standing. Therefore, the research sample consists of the JII (Jakarta Islamic Indexs) and GDP (Gross Domestic Product). The research period is approximately 16 years of observation ranging from 2000 to 2016. Data was obtained from publications on the IDX (Indonesia Stock Exchange) website, OJK (Otoritas Jasa Keuangan) and BPS (Badan Pusat Statistik). Some tests such as the root unit test, cointegration test and Error Correction Model are used to test data. The statistical test tool used was Eviews 9. The Error Correction Model results show that the Islamic stockl market does not affect long-term economic growth.
\end{abstract}

Keyword : Islamic Capital Market, Jakarta Islamic Index, Gross Domestic Product, Economic Growth 


\section{PENDAHULUAN}

Ekonom telah tertarik pada peran ekspansi lembaga keuangan dalam alokasi sumber daya dan pertumbuhan ekonomi. Banyak peneliti sepakat tentang pentingnya peran sektor keuangan dalam pertumbuhan ekonomi riil, baik di tingkat nasional dan internasional (Kunt, Laeven, \& Levine, 2003; Love, 2003; Seven \& Yetkiner, 2015). Sektor keuangan memainkan peran penting jika mampu menyalurkan sumber daya keuangan ke industri dengan peluang pertumbuhan yang baik. Ketika sektor keuangan lebih berkembang, maka lebih banyak sumber daya keuangan dapat dialokasikan ke dalam investasi riil produktif dan lebih banyak modal fisik terbentuk, yang akan merangsang pertumbuhan ekonomi. Sebagai bagian dari perkembangan keuangan, kapabilitas pasar modal Indonesia memberikan kontribusi besar bagi pertumbuhan ekonomi. Pasar modal merupakan pasar untuk jual beli instrument keuangan jangka Panjang, seperti surat utang (obligasi), ekuitas (saham), reksa dana, instrument derivative dan instrument lainnya. Di pasar modal inilah perusahan mendapatkan pendanaan dan sebagai sarana kegiatan investasi.

Investasi adalah kegiatan menanamkan modal dengan harapan mendapatkan pengembalian yang lebih besar di masa yang akan datang. Pasar modal merupakan tempat investasi yang popular di masyarakat Indonesia. Di pasar modal, investor dapat melakukan transaksi jual beli dalam bentuk hutang maupun modal sendiri. Instrument keuangan yang banyak diminati oleh investor adalah saham. Alasannya adalah karena saham mampu memberikan tingkat keuntungan yang menarik, yaitu memperoleh dividen dan capital gain.

Sebagian besar penduduk Indonesia adalah umat muslim. Pengembang pasar modal pun menyadari potensi tersebut untuk menghimpun dana umat muslim untuk diinvestasikan. Salah satu jenis investasi adalah dengan menggunakan instrument pasar modal Syariah. Pasar Modal Syariah adalah kegiatan yang bersangkutan dengan Penawaran Umum dan perdagangan Efek, Perusahaan Publik yang berkaitan dengan Efek yang diterbitkannya, serta lembaga dan profesi yang berkaitan dengan Efek yang tidak bertentangan dengan prinsip syariah (www.ojk.go.id). Fungsi dari Pasar Modal Syariah adalah menyalurkan pihak yang membutuhkan dana dengan pihak yang kelebihan dana.

Pasar saham Syariah di Indonesia terus berkembang pesat. Berdasarkan majalah Insight (Edisi Juni 2019), sudah ada 60 persen saham bersifat Syariah dari kapitalisasi pasar sebesar Rp 7.000 triliun. Sistem online trading-nya mencapai 13 SOTS (Syariah Online Trading System) Syariah. Selanjutnya, seberapa besar kontribusi perkembangan pasar saham Syariah untuk pertumbuhan ekonomi? Beberapa studi teoritis telah dilakukan di berbagai bidang perbankan Islam. Sebagian besar dari mereka menunjukkan keunggulan industri keuangan Islam dibandingkan dengan yang konvensional dalam hal stabilitas dan efisiensi (Hasan \& Dridi, 2010). Namun, hanya sedikit penelitian yang mencari bukti empiris yang menghubungkan keuangan Islam dan pertumbuhan ekonomi. Muye \& Hassan (2016) telah meneliti perkembangan asuransi Islam terhadap pertumbuhan ekonomi. Gazdar, Hassan, Safa, \& Grassa (2018) telah meneliti pengaruh perkembangan keuangan Islam dalam hubungannya dengan volatilitas pertumbuhan perdagangan minyak dan pertumbuhan ekonomi di negara-negara GCC. Rama (2013) meneliti pengaruh perbankan Syariah dengan pertumbuhan ekonomi di Indonesia. Kassim (2016) menyatakan bahwa meningkatnya keberadaan perbankan dan keuangan Islam di sektor keuangan meningkatkan evaluasi kontribusi keuangan Islam terhadap kegiatan ekonomi riil. Selanjutnya Setiawan (2017) meneliti perbandingan kinerja pasar modal Syariah dan konvensional pada pasar modal Indonesia.

Artikel ini bertujuan untuk menguji pengaruh pasar saham Syariah terhadap pertumbuhan ekonomi. Dalam konteks ini, hubungan teoritis dan empiris antara pengembangan pasar saham syariah dan pertumbuhan PDB per kapita riil masih memunculkan bukti kontradiktif. Produk domestik bruto (PDB) adalah nilai pasar semua barang dan jasa yang diproduksi oleh suatu negara pada periode tertentu. PDB merupakan salah satu metode untuk menghitung pendapatan nasional. Berdasarkan informasi Badan Pusat Statistik (BPS), ekonomi Indonesia triwulan III-2018 dibandingkan triwulan III-2017 (y-on-y) tumbuh 5,17 persen dan dibandingkan triwulan III-2018 
(q-to-q) mengalami pertumbuhan sebesar 3,09 persen. Dari sisi produksi pertumbuhan triwulan III2018 (y-on-y) didukung oleh semua lapangan usaha. Pertumbuhan tertinggi dicapai oleh Lapangan Usaha Jasa Lainnya sebesar 9,19 persen yang didorong oleh penyelenggaraan event Internasional. Bila dibandingkan dengan triwulan sebelumnya $(q-t o-q)$, pertumbuhan ekonomi dari sisi produksi oleh masih berlangsungnya pembangunan infrastruktur menyebabkan Lapangan Usaha Konstruksi tumbuh 4,81 persen. Jadi hasil penelitian akan membantu pengambil keputusan dan sarjana ekonomi dalam memahami keuntungan pasar modal Syariah dalam meningkatkan pertumbuhan ekonomi.

Bagian selanjutnya dari paper ini disusun sebagai berikut: Bagian 2 menjelaskan kajian teori yang menjelaskan beberapa pemaparan utuh tentang penelitian. Bagian 3 menjelaskan metode penelitian yang digunakan untuk menjawab pertanyaan penelitian. Bagian 4 melaporkan dan menganalisis dan membahasan hasil dari uji statistik. Bagian 5 memaparkan kesimpulan penelitian secara rinci.

Pasar modal sangat berperan bagi perkembangan perekonomian suatu negara. Pasar modal menjalankan dua fungsi, yaitu fungsi pendanaan dan fungsi investasi. Dalam fungsi pendanaan, pasar modal menjadi sarana perusahaan untuk mendapatkan dana dari masyarakat pemodal (investor). Dana yang diperoleh ini nantinya dapat digunakan untuk pengembangan usaha, ekspansi bisnis, penambahan modal kerja dan lain-lain. Pasar modal sebagai fungsi investasi menjadi sarana bagi masyarakat untuk berinvestasi pada instrument keuangan, seperti saham, sukuk, reksa dana,dan derivarif. Dengan demikian, masyarakat dapat memilih untuk berinvestasi sesuai dengan karakteristik keuangan dan risiko tiap instrument.

Berdasarkan sudut pandang syariah, pasar modal adalah bagian dari aktivitas muamalah (Yafiz, 2008). Transaksi di dalam pasar modal diperbolehkan sepanjang tidak terdapat transaksi yang bertentangan dengan ketentuan yang telah digariskan oleh syariah. Yafiz (2008) dalam tulisannya menceritakan bahwa dalam buku yang berjudul Development of capital market under Islamic principles karya Syed Othman Alhabshi memberikan deskripsi analitis tentang eksistensi pasar modal yang sesuai syariah serta secara optimal dapat berperan terhadap pertumbuhan dan ekspansi ekonomi. Pendekatan analisisnya dengan menerapkan prinsip-prinsip Syariah dalam aktivitas transaksi di pasar modal yang berorientasi kepada tujuan dari penerapan prinsip-prinsip Syariah. Menurut Syed Othman Alhabshi, tujuan-tujuan syariah dalam kehidupan ekonomi tersebut seperti terealisasinya distribusi pendapatan dan kekayaan, terciptanya keadilan dan keseimbangan ekonomi baru akan terwujud dengan diaplikasikannya prinsip-prinsip syariah dalam berbagai aktifitas ekonomi dan keuangan syariah, khususnya pasar modal sebagai lembaga keuangan (financial institustion). Di antara prinsip-prinsip tersebut adalah pelarangan riba (prohibition of interest) sebagaimana tertuang dalam Q.S. al-Baqarah/2: 275-276 dan ayat 278-290.

Definisi pasar modal Syariah dapat diartikan sebagai kegiatan dalam pasar modal sebagaimana yang diatur dalam Undang-Undang Pasar Modal (UUPM) yang tidak bertentangan dengan prinsip syariah. Oleh karena itu, sistem dalam pasar modal Syariah tidak dapat terpisahkan dari system pasar modal secara keseluruhan. Ada perbedaan karakteristik antara pasar modal Syariah dengan pasar modal konvensional, yaitu produk dan mekanisme transaksi tidak bertentangan dengan prinsip-prinsip Syariah. Adapun prinsip-prinsip pasar modal syariah adalah: a. Pelarangan riba (prohibition of interest);b.Pelarangan gharar (prohibition of doubtful transaction), Syariah melarang transaksi yang di dalamnya terdapat spekulasi dan mengandung gharar atau ketidakjelasan yaitu transaksi yang di dalamnya dimungkinkan terjadinya penipuan ( $k$ hida'); c. Melakukan penawaran palsu (najsy); d. Transaksi atas barang yang belum dimiliki (short selling/bai'u mâlaisa bimamluk); e. Menjual sesuatu yang belum jelas (bai'u al ma'dûm); f. Pembelian untuk penimbunan efek (ihtikar) dan menyebarluaskan informasi yang menyesatkan atau memakai informasi orang dalam untuk memperoleh keuntungan transaksi yang dilarang (insider trading); g. Pelarangan untuk bertransaksi terhadap makanan dan minuman yang halal (prohibition of unlawful food ang drink); h. Prinsip kesederhanaan (principle of moderation); $\mathrm{i}$. 
Prinsip etika perilaku (principle of ethical behavior), dan prinsip kepemilikan sempurna (principle of complete ownership).

Prinsip-prinsip tersebut di atas akan menjadi landasan aktifitas ekonomi dan keuangan, khususnya di pasar modal. Dengan adanya berbagai ketentuan Syariah di atas, maka investasi tidak dapat dilakukan terhadap semua produk pasar modal karena di antara produk pasar modal harus dilakuan dengan hati-hati (ihtiyat) agar tidak masuk kepada produk non halal.

Pasar Modal Syariah di Indonesia dimulai dengan diterbitkannya Reksa Dana Syariah oleh PT. Danareksa Investment Management pada 3 Juli 1997. PT. Danareksa Investment Management bekerja sama dengan Bursa Efek Indonesia (BEI) meluncurkan Jakarta Islamic Index (JII) pada tanggal 3 Juli 2000. Konstituen JII hanya terdiri dari 30 saham syariah paling likuid yang tercatat di BEI. Selanjutnya pada tanggal 17 Mei 2018 BEI meluncurkan Jakarta Islamic Index 70 (JII70). Konstituen JII70 hanya terdiri dari 70 saham syariah paling likuid yang tercatat di BEI. Dengan hadirnya indeks tersebut, maka para pemodal telah disediakan saham-saham yang dapat dijadikan sarana berinvestasi sesuai dengan prinsip syariah. Salah satu alasan dikembangkannya pasar modal Syariah adalah untuk mengakomodir kebutuhan umat Islam yang ingin melakukan investasi di pasar modal yang sesuai dengan prinsip Syariah (Fauzan \& Suhendro, 2018).

Ramadhan (2016) menjelaskan bahwa ada dua hal utama dalam pasar modal syariah yaitu indeks Islam dan pasar modal syariah itu sendiri. Indeks Islam menunjukkan pergerakan harga-harga saham dari emiten yang dikatagorikan sesuai syariah, sedangkan pasar modal syariah merupakan institusi pasar modal sebagaimana lazimnya yang diterapkan berdasarkan "prinsip-prinsip syariah". Perbedaan pasar modal konvensional dengan pasar modal Syariah utamanya adalah bahwa dalam pasar modal Syariah tidak mengenal kegiatan perdagangan short selling, yaitu jual beli dalam waktu singkat untuk mendapatkan keuntungan antara selisih jual dan beli. Pemegang saham Syariah merupakan investor jangka Panjang yang hanya mengutamakan pencapaian keuntungan akan dibagi atau kerugian akan ditanggung Bersama (profit-loss sharing).

Saham syariah merupakan salah satu efek yang diperdagangkan di dalam pasar modal syariah. Pada dasarnya saham syariah sama dengan saham dalam pasar modal konvensional. Perbedaannya adalah bahwa saham yang diperdagangkan dalam pasar modal syariah harus berasal dari emiten yang memenuhi kriteria-kriteria syariah (Syariah Compliance). Dengan demikian, kalau saham merupakan surat berharga yang merepresentasikan penyertaan modal kedalam suatu perusahaan, maka dalam prinsip syariah, penyertaan modal dilakukan pada perusahaan-perusahaan yang tidak melanggar prinsip-prinsip syariah, seperti bidang perjudian, riba, memproduksi barang yang diharamkan seperti bir, dan lain-lain.

Saham merupakan surat berharga dalam penyertaan modal kepada perusahaan. Saham juga merupakan bukti bahwa investor berhak untuk mendapatkan bagian hasil dari usaha perusahaan tersebut. Penyertaan modal dengan hak bagian hasil usaha tidak bertentangan dengan prinsip Syariah. Prinsip tersebut dikenal sebagai kegiatan musyarakah atau syirkah. Namun, tidak semua saham yang diterbitkan oleh emiten dapat disebut sebagai saham Syariah. Berikut ini adalah beberapa karakteristik saham Syariah jika saham tersebut diterbitkan oleh emiten dan Perusahaan Publik yang secara jelas menyatakan dalam anggaran dasarnya bahwa kegiatan usaha Emiten dan Perusahaan Publik tidak bertentangan dengan Prinsip-prinsip syariah, emiten dan Perusahaan Publik yang tidak menyatakan dalam anggaran dasarnya bahwa kegiatan usaha Emiten dan Perusahaan Publik tidak bertentangan dengan Prinsip-prinsip syariah, namun memenuhi kriteria sebagai berikut, kegiatan usaha tidak bertentangan dengan prinsip syariah sebagaimana diatur dalam peraturan IX.A.13, yaitu tidak melakukan kegiatan usaha perjudian dan permainan yang tergolong judi; perdagangan yang tidak disertai dengan penyerahan barang/jasa; perdagangan dengan penawaran/permintaan palsu; bank berbasis bunga; perusahaan pembiayaan berbasis bunga; jual beli risiko yang mengandung unsur ketidakpastian(gharar) dan/atau judi (maisir), antara lain asuransi konvensional; memproduksi, mendistribusikan, memperdagangkan dan/atau 
menyediakan barang atau jasa haram zatnya (haram li-dzatihi), barang atau jasa haram bukan karena zatnya (haram li-ghairihi) yang ditetapkan oleh DSN-MUI; dan/atau, barang atau jasa yang merusak moral dan bersifat mudarat; melakukan transaksi yang mengandung unsur suap (risywah);

Pertumbuhan ekonomi (economic growth) adalah perkembangan kegiatan dalam perekonomian yang menyebabkan barang dan jasa yang diproduksikan dalam masyarakat bertambah dan kemakmuran masyarakat meningkat. Rama (2013) menjelaskan bahwa setidaknya ada empat kemungkingan pendekatan yang bisa menjelaskan hubungan antara sector keuangan dan pertumbuhan, yaitu (1) keuangan adalah factor penentu pertumbuhan ekonomi (finance-led growth hypothesis) atau biasa disebut "supply-leading view, 2) keuangan mengikuti pertumbuhan ekonomi (growth-led finance hypothesis) atau biasa disebut "demand-following view", 3) hubungan saling mempengaruhi antara keuangan dan pertumbuhan atau biasa disebut "the bidirectional causality view", dan 4) keuangan dan pertumbuhan tidak saling berhubungan atau biasa disebut "the independent hypothesis".

Masalah pertumbuhan ekonomi dapat dipandang sebagai masalah makro ekonomi dalam jangka panjang. Perkembangan kemampuan memproduksi barang dan jasa sebagai akibat pertambahan faktor-faktor produksi pada umumnya tidak selalu diikuti oleh pertambahan produksi barang dan jasa yang sama besarnya. Pertambahan potensi memproduksi sering kali lebih besar dari pertambahan produksi yang sebenarnya. Fauzan \& Suhendro (2018) memaparkan beberapa hal yang dapat mempengaruhi pertumbuhan ekonomi, yaitu: a. Akumulasi Modal, Capital accumulation terjadi sebagian dari pendapatan ditabung dan diinvestasikan kembali dengan tujuan memperbesar output. Pengadaan peralatan kerja, mesin-mesin, bahan baku dapat meningkatkan stok modal suatu negara dan memungkinkan terjadinya peningkatan output di masa mendatang. $b$. Pertumbuhan Penduduk dan Angkatan Kerja, Secara tradisional dianggap sebagai salah satu faktor positif yang memacu pertumbuhan ekonomi. Dimana jumlah tenaga kerja lebih besar akan menambah tenaga yang produktif. Di negara berkembang kelebihan tenaga kerja bukan menjadi hal positif atau negatif tetapi sepenuhnya tergantung kepada kemampuan system perekonomian yang bersangkutan untuk menyerap dan memanfaatkan tenaga kerja tersebut. c. Kemajuan Teknologi, Bagi kebanyakan ekonom merupakan sumber pertumbuhan ekonomi yang sangat penting. Kemajuan teknologi terjadi karena ditemukan cara baru yang efektif untuk menangani setiap pekerjaan.

\section{METODE PENELITIAN}

Dalam penelitian ini, regresi pertumbuhan time-series digunakan untuk evaluasi empiris apakah indeks pengembangan pasar saham syariah terhubung dengan pertumbuhan ekonomi. Analisis empiris ini dilakukan selama periode 2000 hingga 2016. Data diperoleh dari publikasi di website IDX (Indonesia Stock Exchange), OJK (Otoritas Jasa Keuangan) dan BPS (Badan Pusat Statistik). Indeks saham Syariah yang digunakan adalah Jakarta Islamic Index (JII) yang telah beridiri lama. Data yang digunakan adalah data saham saja, karena untuk informasi mengenai sukuk tersedia mulai tahun 2011. Jika sukuk ditambahkan ke dalam model penelitian maka akan mengurangi panjangnya pengamatan. Dengan demikian, penelitian ini fokus pada kontribusi saham Syariah terhadap pertumbuhan ekonomi Indonesia. Alat uji statistik yang digunakan adalah Eviews 9.

Pertumbuhan ekonomi per kapita (PDB) dilambangkan dengan G. Pertumbuhan (growth) adalah variabel dependen yang merupakan data time series dari indikator pertumbuhan ekonomi selama periode penelitian. Saham adalah variabel independen yang merupakan data time series dari indikator pasar saham selama periode penelitian dan diproksikan oleh Market Capitalization Ratio (MCR). MCR dihitung dengan membagi nilai perusahaan yang terdaftar (kapitalisasi pasar) dengan PDB. MCR mengukur ukuran (size) pasar saham dalam kaitannya dengan ukuran ekonomi dan merupakan ukuran yang berguna dari ukuran relatif pasar saham dalam perekonomian. Kemudian struktur persamaan regresi adalah di mana semua data dinyatakan dalam logaritma untuk mengendalikan konvergensi, untuk memasukkan efek proliferasi dari deret waktu dan 
disimbolkan dengan huruf ln yang menunjukkan logaritma natural yang mendahului setiap nama variable.

Untuk fokus pada dampak empiris dari perkembangan pasar saham pada pertumbuhan ekonomi, model pertumbuhan dapat dilihat dalam persamaan 1. Model ini diambil dari bagian model umum yang lebih lengkap dan variabel yang digunakan didasarkan pada teori ekonomi dan diusulkan oleh studi teoritis dan empiris, seperti (Atje \& Jovanovic, 1993; Beck, Levine, \& Loayza, 2000). Untuk menguji hubungan kausal, model multivariat berikut harus diperkirakan. Persamaan 1 $\ln G t=a 0+a \ln M C R t+u$, dimana $G=$ produk domestik bruto $(\mathrm{PDB}) u=$ error term

\section{HASIL DAN PEMBAHASAN}

Estimasi model ekonometrik time series akan menghasilkan kesimpulan yang tidak berarti ketika data yang digunakan mengandung akar unit (tidak stasioner) (Rama, 2013). Time series dikatakan stasioner jika rata-rata varians dan kovariansnya konstan sepanjang periode waktu. Untuk melihat stasionaritas variabel time series maka penelitian ini menggunakan Augmented Dickey-Fuller test (ADF test) yang diperkenalkan oleh Dickey Fuller (1979) dan Phillips-Perron test (PP test) yang diperkenalkan oleh Phillips Perron (1988).

Pada uji Unit Root (Augmented Dikey Fuller Unit Root Test) ada beberapa kriteria, yaitu H0: ada unit root, Ha: tidak ada unit root. Tingkat signifikansi sebesar $95 \%$ atau $\alpha=5 \%$. Daerah kritis H0 ditolak jika Nilai ADF < critical value $(\alpha=5 \%)$, dan H0 diterima jika Nilai ADF > critical value $(\alpha=5 \%)$. Berikut ini akan dilakukan uji root pada data PDB dan MCR. Tabel 1 memaparkan hasil dari uji unit root untuk data Pendapatan Domestik Bruto (PDB).

Tabel 1. Uji unit root untuk Data PDB

\begin{tabular}{lccc}
\hline & & t-Statistic & Prob.* \\
\hline Augmented Dickey-Fuller test statistic & -2.328088 & 0.3963 \\
Test critical values: & 1\% level & -4.728363 & \\
& 5\% level & -3.759743 & \\
& 10\% level & -3.324976 & \\
\hline
\end{tabular}

Sumber: diolah oleh peneliti (2019)

Dari hasil uji di atas disimpulkan bahwa H0 diterima karena statistik uji $\operatorname{ADF}(-2.328088)>$ nilai kritis ADF pada $\alpha=5 \%(-3.759743)$ dan juga nilai prob $(0.3963)>0.05$. Dengan demikian data PDB mngandung unit root atau data tidak stasioner.

Tabel 2. Uji unit root untuk Data MCR

\begin{tabular}{lccc}
\hline & & t-Statistic & Prob.* \\
\hline Augmented Dickey-Fuller test statistic & -2.207544 & 0.4544 \\
Test critical values: & 1\% level & -4.667883 & \\
& 5\% level & -3.733200 & \\
& 10\% level & -3.310349 & \\
\hline
\end{tabular}

Sumber: diolah oleh peneliti (2019)

Dari Tabel 2, hasil uji di atas disimpulkan bahwa H0 diterima karena statistic uji ADF(-2.207544) $>$ nilai kritis ADF pada $\alpha=5 \%(-3.759743)$ dan juga nilai prob $(0.4544)>0.05$. Dengan demikian data MCR mngandung unit root atau data tidak stasioner.

Berdasarkan uji unit root tampak bahwa data PDB dan MCR tidak stasioner. Selanjutnya akan dilanjutkan uji kointegrasi antara kedua variabel menggunakan Uji Engle-Granger dengan melihat stasioneritas dari residual hasil regresi antara PDB dan MCR. 
Melakukan regresi antara PDB dan MCR

Tabel 3. Hasil Regresi antara PDB dan MCR

\begin{tabular}{lllll}
\hline Variable & Coefficient & Std. Error & t-Statistic & Prob. \\
\hline MCR & 14.75941 & 2.943019 & 5.015057 & 0.0002 \\
C & 2.558406 & 2.547439 & 1.004305 & 0.3312 \\
R-squared & 0.626408 & & & \\
Adjusted R-squared & 0.601502 & & & \\
F-statistic & 25.15079 & & & \\
Prob(F-statistic) & 0.000154 & & & \\
\hline
\end{tabular}

Sumber: diolah oleh peneliti (2019)

Membuat data residual yang baru yang merupakan replikasi dari data resid menggunakan genered equation dilanjutkan dengan stattioneritas residual.

Tabel 4. Hasil Augmented Dickey-Fuller Test

\begin{tabular}{lccc}
\hline & & t-Statistic & Prob.* \\
\hline Augmented Dickey-Fuller test statistic & -5.820967 & \multirow{2}{*}{0.0017} \\
Test critical values: & 1\% level & -4.728363 & \\
& 5\% level & -3.759743 & \\
& 10\% level & -3.324976 & \\
\hline
\end{tabular}

Sumber: diolah oleh peneliti (2019)

Dari hasil di atas disimpulkan bahwa, H0 ditolak karena statistik uji ADF (-5.820967) < nilai kritis ADF pada $\alpha=5 \%$ (-3.759743). Dengan demikian residual tidak mengandung unit root dengan kata lain data stationer. Sehingga diperoleh persamaan regresi kointegrasi sebagai berikut: $\mathrm{PDB}=$ $2.558406+14.75941 \mathrm{MCR}$

Dengan mengetahui kedua data saling berkointegrasi, berarti ada hubungan jangka panjang (equilibrium) antara kedua variabel tersebut. Dalam jangka pendek ada kemungkinan terjadi ketidakseimbangan. Karena adanya ketidakseimbangan ini maka diperlukan adanya koreksi dengan model koreksi kesalahan (error correction Model, ECM). Persamaan untuk ECM sederhana dapat ditulis sebagai berikut: $\Delta(\mathrm{PDB})=C+\lambda \mathrm{e}_{\mathrm{t}-1}+\grave{\omega}_{0} \Delta(\mathrm{MCR})+\mathbb{e}_{1}$

Tabel 5. Estimasi Errror Correction Model

\begin{tabular}{lllll}
\hline Variable & Coefficient & Std. Error & t-Statistic & Prob. \\
\hline C & 0.133886 & 0.007049 & 18.99238 & 0.0000 \\
D(MCR) & -0.103693 & 0.275708 & -0.376098 & 0.7129 \\
RESID04(-1) & -0.088055 & 0.016838 & -5.229570 & 0.0002 \\
R-squared & 0.709052 & & & \\
Adjusted R-squared & 0.664290 & & & \\
Prob(F-statistic) & 0.000327 & & & \\
\hline
\end{tabular}

Sumber: diolah oleh peneliti (2019)

Untuk persamaan jangka pendek, nilah probabilitas F-statistik berada di bawah alpha (0.05). Koefisien dari resid04(-1) nilainya adalah negatif dan signifikan (probabilitas berada di bawah 0.05). Untuk variabel MCR ternyata nilainya (0.7129), artinya tidak signifikan atau berada di atas alpha (0.05). Hasil pengujian dalam model ini membuktikan bahwa dalam jangka panjang pasar modal Syariah (MCR) tidak berpengaruh terhadap pertumbuhan ekonomi (PDB).

Pertumbuhan ekonomi penting dan dibutuhkan untuk mempersiapkan kemajuan perekonomian. Berikut ini adalah beberapa alasan pentingnya pertumbuhan ekonomi (Hayati, 2014), yaitu Peningkatan Kesejahteraan, kesejahteraan rakyat dapat dilihat dari hasil per kapita yang 
meningkat. Tingkat kesejahteraan tersebut diukur dengan PDB per kapita. Agar PDB per kapita terus meningkat, maka perekonomian harus terus tumbuh dan lebih tinggi daripada tingkat pertumbuhan penduduk. Kesempatan Kerja, islam memandang aktivitas produksi merupakan bagian dari kewajiban untuk menciptakan kemakmuran semesta. Tingkat pengangguran ang minimal akan tercapai jika seluruh kapasitas produksi terpakai kesempatan kerja penuh. Perbaikan Distribusi Pendapatan, distribusi pendapatan yang baik adalah jika pendapatan semakin merata. Jika pertumbuhan ekonomi tidak mengalami peningkatan, maka yang terjadi adalah pemerataan kemiskinan.

Periode penelitian ini kurang lebih selama 16 tahun amatan mulai dari tahun 2000 sampai 2016. Selama periode tersebut terjadi perkembangan dan pergerakan pasar global yang menyebabkan pasar saham Indonesia mengalami periode naik turun. Seperti krisis subprime mortgage di Amerika tahun 2007/2009. Jakarta Islamic Index (JII) hanya mengikutsertakan saham-saham yang sesuai dengan prinsip syariah. Prinsip syariah yang harus dipenuhi antara lain terhindarnya aktivitas pasar modal syariah dari unsur perjudian (maysir), ketidakpastian (gharar), sistem bunga (riba), dan ketidakadilan. Hasil penelitian (Setiawan, 2017) membuktikan bahwa kinerja pasar modal konvensional (JCI) lebih baik dibandingkan kinerja pasar modal Syariah (JII) di Indonesia selama periode tahun 1995 - 2015. Perhitungan kinerja indeks menggunakan Sharpe, Treynor, dan Jensen Alfa pada periode sebelum krisis Asia, saat krisis Asia, sebelum krisis subprime mortgage, saat krisis subprime mortgage. Hasil penelitin ini mendukung penelitian (Setiawan, 2017) bahwa kinerja JII kalah dibanding dengan kinerja pasar modal konvensional (JCI). Karena kinerja JII tidak sebaik dengan kinerja pasar modal konvensional, maka pasar saham Syariah tidak berpengaruh terhadap pertumbuhan ekonomi (PDB).

\section{KESIMPULAN}

Tujuan dari artikel ini adalah untuk mempelajari hubungan sebab akibat antara pertumbuhan ekonomi dan pasar saham Syariah di Indonesia selama 2000-2016. Tes unit root, tes cointergration dan Error Correction Model digunakan untuk menguji hubungan ini. Artikel ini fokus pada indeks JII (Jakarta Islamic Index) yang merupakan indeks Syariah pertama di Indonesia. Hasil Error Correction Model menunjukkan bahwa pasar saham Syariah tidak berpengaruh terhadap pertumbuhan ekonomi dalam jangka Panjang.

Penelitian ini merupakan preliminary research untuk menjawab kegalauan peneliti mengenai hubungan antara pasar saham Syariah dengan pertumbuhan ekonomi di Indonesia. Kontribusi utama adalah berkaitan dengan pengembangan keilmuan. Hasil penelitian membuktikan bahwa pasar saham Syariah tidak berpengaruh terhadap pertumbuhan ekonomi dalam jangka Panjang. Temuan ini tentunya bertentangan dengan teori yang telah ada. Banyak keterbatasan yang dialami ketika melakukan penelitian. Pertama, penelitian ini hanya menggunakan indeks JII untuk menentukan kapitalisasi saham syariah dan mengabaikan sukuk dan reksa dana. Data mengenai sukuk mulai disajikan tahun 2011 dan informasi reksa dana Syariah tahun 2010. Kedua, banyak data historis yang tidak tersedia atau dipublikasikan di IDX. Proxi untuk pengembangan pasar modal pada penelitian selanjutnya bisa ditambahkan dengan NST (Number of Shares Traded), VSTR (Value of Share Traded Ratio), dan NT( Number of Transactions). Namun data untuk mencari rasio-rasio tersebut tidak tersedia. Ketiga, penelitian ini hanya menggunkan satu model penelitian dengan menggunakan PDB. Padahal jenis PDB itu luas sekali, seperti PDB riil nonminyak juga dapat dipertimbangkan dalam penelitian selanjutnya. Karena selain berpengaruh pada investasi, jatuhnya harga minyak mempengaruhi ekonomi potensial lebih lanjut.

\section{DAFTAR PUSTAKA}

Atje, R., \& Jovanovic, B. (1993). Stock markets and development. European Economic Review, 37(2-3), 632-640. https://doi.org/10.1016/0014-2921(93)90053-D

Beck, T., Levine, R., \& Loayza, N. (2000). Finance and the sources of growth. Journal of Financial Economics, 58, 261-300. 
Fauzan, M., \& Suhendro, D. (2018). Peran pasar modal syariah dalam mendorong laju pertumbuhan ekonomi di indonesia. In Prosiding SENDI.

Gazdar, K., Hassan, M. K., Safa, M. F., \& Grassa, R. (2018). Oil price volatility, Islamic financial development and economic growth in Gulf Cooperation Council (GCC) countries. Borsa Istanbul Review, 1-10. https://doi.org/10.1016/j.bir.2018.07.005

Hasan, M., \& Dridi, J. (2010). The Effects of the Global Crisis on Islamic and Conventional Banks: A Comparative Study.

Hayati, S. R. (2014). Peran Perbankan Syariah terhadap Pertumbuhan Ekonomi Indonesia. IndoIslamika, 4(1), 41-66.

Kassim, S. (2016). Islamic finance and economic growth: The Malaysian experience. Global Finance Journal, 30, 66-76. https://doi.org/10.1016/j.gfj.2015.11.007

Kunt, A. D., Laeven, L., \& Levine, R. (2003). Regulations, Market Structure, Institutions, and The Cost of FInancial Intermediation.

Love, I. (2003). Financial Development and Financing Constraints: International Evidence from the Structural Investment Model. Review of Financial Studies, 16(3), 765-791. https://doi.org/10.1093/rfs/hhg013

Muye, I. M., \& Hassan, A. F. S. (2016). Does Islamic Insurance Development Promote Economic Growth? A Panel Data Analysis. Procedia Economics and Finance, 35(October 2015), 368-373. https://doi.org/10.1016/S2212-5671(16)00045-9

Rama, A. (2013). Perbankan Syariah Dan Pertumbuhan Ekonomi Indonesia. Signifikan: Jurnal Ilmu Ekonomi, 2(1), 33-56. https://doi.org/10.15408/sjie.v2i1.2372

Ramadhan, S. (2016). Pasar uang dan pasar modal dalam perspektif ekonomi islam. Al-Masraf: Jurnal Lembaga Keuangan Dan Perbankan, 1(2), 197-210. Retrieved from http://journal.febi.uinib.ac.id/index.php/almasraf/article/view/56

Setiawan, B. (2017). Perbandingan Kinerja Pasar Modal Syariah Dan Konvensional : Suatu Kajian Empiris Pada Pasar Modal Indonesia. Jurnal Ilmiah Ekonomi Global Masa Kini, 8(01), 3540. Retrieved from file://C:/Users/LENOVO/Downloads/Documents/234-650-1-PB.pdf

Seven, Ü., \& Yetkiner, H. (2015). Financial intermediation and economic growth: Does income matter? Economic Systems, 40(1), 1-20. https://doi.org/10.1016/j.ecosys.2015.09.004

Yafiz, M. (2008). Saham Dan Pasar Modal Syariah : Miqot, XXXII(2), 240-241. 